International Journal of Applied Linguistics \& English Literature

ISSN 2200-3592 (Print), ISSN 2200-3452 (Online)

Vol. 1 No. 7; November 2012 [Special Issue on Applied Linguistics]

\title{
Student Feedback or 'Students Hit Back': in Search of Quality Feedback for Quality Teaching
}

\author{
Abdel Rahman Abdalla Salih, PhD \\ Al-Zahra University College for Women \\ Department of English Language and Literature \\ P.O. Box: 3365-P.C:111-Airport Heights, Muscat \\ Sultanate of Oman \\ GSM: +968-92368309 E-mail: aykistar@gmail.com
}

Received: 12-09- 2012

doi:10.7575/ijalel.v.1n.7p.90
Accepted: 25-10- 2012

Published: 25-11- 2012

URL: http://dx.doi.org/10.7575/ijalel.v.1n.7p.90

\begin{abstract}
Universities and colleges often administer student feedback surveys on teaching to elicit students' views of how a particular course is taught and learned in order to improve teaching quality by helping tutors increase opportunities for better learning. This paper reports the views of (40) English teachers and (124) General Foundation Programme (GFP) students on student feedback in institutions of higher education in the Sultanate of Oman, and the implications of such perceptions on the quality of teaching and learning English language. Findings reveal variation in the views held by both teachers and students about student feedback on teaching and learning experience. The study confirms the need for consistency between the perceptions of teachers and students on student feedback, and for training students on quality feedback and reflective learning.
\end{abstract}

Keywords: Quality assurance, student feedback, teacher response, quality teaching, transformative reflection, teacher perception

\section{Introduction}

English Language Teaching (ELT) together with the growth of English as a Second or Foreign Language $(\mathrm{ESL} / \mathrm{EFL})$ is a progressive field that often witnesses revolutions and innovations. Teachers, researchers, and practitioners are in continuous search for the best teaching tools and practices that can help learners succeed in their language learning and meet the employment criteria and market needs. According to Cook (2003), that "different approaches to teaching English did not just occur by chance, but in response to changing geopolitical circumstances and social attitudes and values, as well as to shifts of fashion in linguistics which, for all its apparent objectivity, was itself subject to social change" (p.30). In response to the increasing demand for quality teaching and learning, particularly in the ESL/EFL contexts, quality assurance (QA) system has evolved, from the outset of its inception, as a peculiar and unique practice in the higher education new agenda. In their quest for quality education, institutions of higher learning often adopt a set of policies and procedures to ensure that quality learning is achieved by quality teaching. This equation rests on clearly-articulated quality assurance philosophy which requires teachers to continuously reflect on their teaching, and to motivate students to view learning as meaningful and useful. Effective teaching, as a requirement of quality education for meaningful and quality learning, then presents students and teachers with continuous demands and challenges. Teachers must develop transformative reflection, adjust their teaching strategies and decisions and set the suitable learning setting for meaningful practices. Students on the other hand, must always reflect on their learning experience and approach learning with positive expectations. In this context, Biggs \& Tang (2007) argued that "effective teaching requires that we eliminate those aspects of our teaching that encourage surface approaches to learning and that we set the stage properly so that students can more readily use deep approaches to learning"(p.31). Thus, effective teaching and professional development geared towards quality learning are motivated by transformative reflection gained by teachers as they receive feedback on their teaching. One of the sources of teacher reflection is the direct feedback students provide on the courses they learn. This process of obtaining direct information from students on their experience of learning and teaching, though regarded an essential quality assurance procedure, is believed to be shaped by a number of factors such as the students' awareness of 


\section{International Journal of Applied Linguistics \& English Literature}

ISSN 2200-3592 (Print), ISSN 2200-3452 (Online)

Vol. 1 No. 7; November 2012 [Special Issue on Applied Linguistics]

their role in evaluating a course they learned, and their seriousness in evaluating teachers. The involvement of students in providing feedback on their learning experience and teachers' performance is a salient feature of quality assurance system in a sense that it provides a platform for students to make their voice heard. In support of exploring the views and expectations of both teachers and students about the learning and teaching processes, Jean \& Simard (2011) argued that "knowing how both parties perceive the efficacy of the ways in which teaching and learning are taking place is consequently of prime importance" (p.467). It is worth noting that an examination of the summative information provided by students on teaching is imperative. In addition, the involvement of students in the quality assurance procedures needs to be monitored and carefully planned for, thus making a better platform for formative perspective. Therefore, it is necessary to eliminate the negative elements which may jeopardize the supreme goal of such an important procedure.

\subsection{Why Evaluate Teacher?}

The implementation of quality assurance polices has changed the scene in university teaching and learning where traditional practices are no longer valid. According to Danielson \& McGreal (2000) that "one factor fueling the shift has been an expanded understanding of learning, and what constitutes good teaching" (p.7). As far as quality teaching is concerned, quality-oriented teaching is believed to be grounded on continuous reflection by teachers in order to motivate students' active engagement in the learning process (Cowan, 2006). Thus, teachers are required to continuously develop transformative reflection by receiving aspects on their teaching from sources including their students. Biggs \& Tang (2007) argued that "a characteristic of award-winning university teachers is their willingness to collect student feedback on their teaching, in order to see where their teaching might be improved" (p.41). The exercise of receiving feedback through self-directed assessment is also supported by perspectives obtained from student feedback questionnaires for the purposes of quality assurance and teachers' professional development. Thus, "surveys can offer highly valuable insights into a teacher's performance, and they can provide feedback to teachers that is unavailable from any other source" (Danielson \& McGreal, 2000, p. 51). It is observed that the current practice in teacher evaluation bears on summative and informative feedback as an indicator of a teacher performance where the former is used for promotion decision making and the latter for the purpose of enhancing teacher professional development and good practices.

\section{Review of Literature}

Recent research on quality teaching and learning has focused mainly on the procedural aspects and significance of student feedback on teaching. Leckey \& Neill (2001) reported the importance of continuous evaluation of quality procedures in higher education in the UK. They focused on the factors affecting quality management and enhancement as the poorest graded area. The researchers examined the failure of higher education institutions to implement students' feedback, and concluded that the views of students whether on the courses they learn, teaching quality or learning quality and experience is of paramount significance in the quality assurance system. It could be argued that, assessing the feedback of students on a particular course is useful in giving a clearer picture of the teaching and learning processes.

In another study, Douglas \& Douglas (2006) compared students' evaluation of teaching quality and peer review of teaching to see the significance of each on the teaching quality. The researchers reported that teachers have great doubt about student feedback. The findings of their study drew attention to the fact that student feedback as an indicator for teacher performance must be implemented carefully and with clearly stated goals in order to have fair and comprehensive results. In another study, Zerihun et al (2011) examined teachers' and students' views on learning and teaching and the impact of that on the evaluation of teaching. The researchers found that both teachers and students valued teaching as an activity for passing knowledge, and assessment as recall of knowledge. The study is significant as it correlated students' conceptions of teaching and assessment and shed some light on the significance of investigating students' and teachers' perceptions of teaching and learning. Research has also attempted to assess the involvement of students in providing feedback. Josefson et al (2011) evaluated the impact of students' participation in providing feedback in Sweden universities. The researchers called for assessing the involvement of students in providing feedback since they are viewed as key partners in the university's activities. On the other hand, Cheng (2011) observed the necessity for addressing the gap between teachers' definition of quality and students' understanding of quality. The latter tend to relate quality to teaching practice rather than their reflective experience as learners.

The growing volume of research in quality assurance practices in higher education has focused on the value of student feedback on teaching and learning. However, little is known about EFL teachers' and students' perceptions towards student feedback on learning experience and teachers. This paper analyses English teachers' 


\section{International Journal of Applied Linguistics \& English Literature \\ ISSN 2200-3592 (Print), ISSN 2200-3452 (Online)}

Vol. 1 No. 7; November 2012 [Special Issue on Applied Linguistics]

and foundation students' perceptions on student feedback and the implications of such perceptions on the quality of teaching and learning English language at the General Foundation Programme (GFP) in higher education institutions in Oman. The study's problem can be encapsulated in the following specific questions.

1. How do teachers perceive students' feedback?

2. Do students and teachers hold compatible understanding of feedback as a quality requirement?

3. How do students evaluate teacher performance?

4. What are the effects of student feedback on teacher performance?

5. To what extent is the student feedback quality-driven?

\section{Method and Procedures}

This study is exploratory in nature in a sense that it investigates teachers' and students' reactions towards the feedback provided by EFL students on their experience of learning and teaching, focusing on perceptions rather than production, with the use of minimal statistical analysis. To achieve such an objective, 2 questionnaires (see Appendix A-Teacher Questionnaire, \& Appendix B- Student Questionnaire) were designed by the researcher and distributed to total of (40) teachers of English and (124) GFP students in (2) higher learning institutes in the Sultanate of Oman. The teachers who took part in this study comprised a group of (40) professionals with varieties of teaching experiences, while the (124) GFP students represented a group of EFL learners with different levels, aptitudes, learning experience, and proficiency in English.

\subsection{Procedures}

This study utilized one source of data: questionnaire surveys. The questionnaires were designed to explore the respondents' perceptions about the feedback obtained from students on their experience of learning and teaching English language at the GFP. The questionnaires were also administered to understand the effects of student feedback on the teaching process and teacher professional growth and development.

\section{Results and Discussion}

As stated above, the questionnaires were designed to elicit the respondents' perceptions about the views of students on teaching and learning as a fundamental requirement in the quality assurance system and teacher professional development. The teacher questionnaire sheets (40 sheets in 24 items), and student questionnaire (124 sheets in 22 items) were collected and analysed to examine the respondents' views on student feedback. Frequencies for both teacher and student questionnaires were taken and categorised separately. The results of teacher questionnaire were shown and discussed under the categories of 'teachers' perceptions on student feedback, Figure1, effects of student feedback, Figure2, factors affecting student feedback, Figure 3, feedback quality, Figure4, training students for quality feedback, Figure5, and significance of learner feedback, Figure6. On the other hand, the students' responses were analysed and categorised under the themes of awareness of feedback significance, Figure7, factors shaping students' decisions, Figure8, teaching skills and teacher personality, Figure9, focus on the teacher, Figure10, and training for quality feedback, Figure11. The results of teacher and student questionnaires were shown and discussed below.

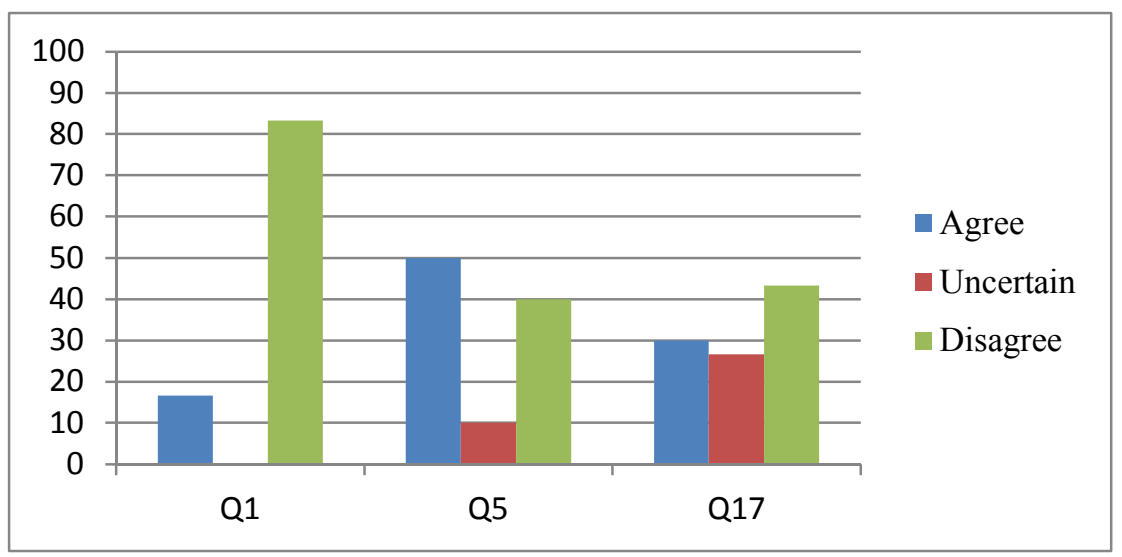

Teacher Questionnaire (Figures 1- 6)

Figure1-T: Teachers' perceptions on student feedback 
International Journal of Applied Linguistics \& English Literature

ISSN 2200-3592 (Print), ISSN 2200-3452 (Online)

Vol. 1 No. 7; November 2012 [Special Issue on Applied Linguistics]

Figure1, above summarises teachers' perceptions on student feedback. Item (1) in the questionnaire addresses the idea that student feedback is not necessary. The analysis revealed that $83 \%$ of the respondents disagreed with the idea that student feedback is not necessary, and $17 \%$ perceived it as less important. The positive response teachers provided indicates the positive perception they hold for student feedback. This result serves the issue addressed in the study's first question pertaining to teachers' perceptions about the views of students on teaching and learning. In addition, this finding confirms the views of Danielson \& McGreal, (2000) on the significance of student feedback for teachers. On the other hand, $50 \%$ of the respondents agreed and $40 \%$ disagreed with the idea of discussing students' feedback in class, while $10 \%$ remained uncertain (item 5). This draws attention to the significance of viewing students as key participants in the learning process whose views are of paramount significance for effective teaching. On limiting student feedback only to the course they learn (item 17), $30 \%$ agreed, $43 \%$ disagreed, and $27 \%$ remained uncertain. It is observed here that a recognisable portion of the respondents preferred a wider focus of student feedback surveys so that they could get more comprehensive feedback on the subjects as well as other teaching-related aspects.

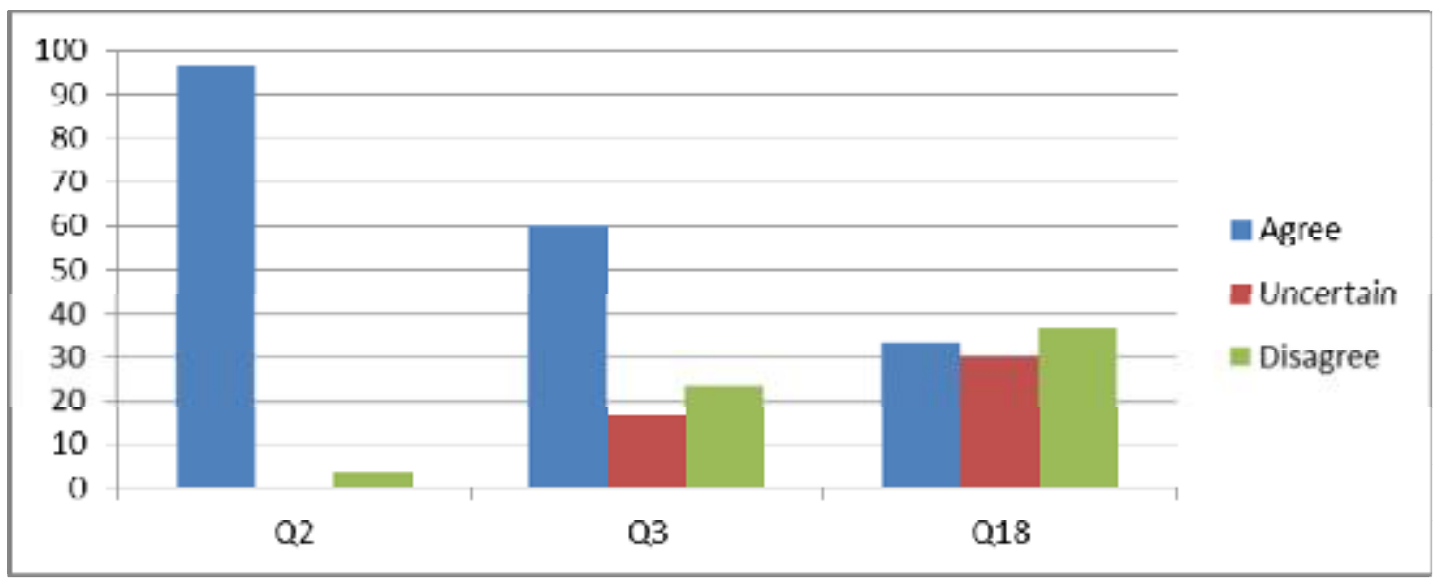

Figure2-T: Effects of student feedback

Items (2), (3), and (18) in Figure2 above, addressed the impact of student feedback as perceived by the teachers. The analysis showed that $97 \%$ agreed, and only 3\% disagreed that student feedback enabled them to be more reflective (item2). In the same vein, the analysis of item (3) revealed that $60 \%$ of the respondents agreed, and $23 \%$ disagreed that they always respond to the students' comments by adjusting their teaching skills. However, $17 \%$ of the respondents remained uncertain of their stand. This result which addresses question 4 in the study suggests that teachers benefit from the perspective provided by the students since that helps them in decision making, adjusting and improving their teaching. In this context, it could be argued that reflective teachers are dynamic and susceptible to transformation, growth and development. This idea is supported by Biggs \& Tang (2007) who suggest that "expert teachers continually reflect on how they might teach even better" (p.41). The analysis of item (18) revealed somewhat similar responses of agreement $33 \%$, uncertainty $30 \%$, and disagreement $37 \%$ about the effects of student feedback on teachers' strategies for assessing students' performance. This result could be attributed to the nature of the assessment policies and procedures undertaken in the GFPs in many institutions of higher learning with team teachers and coordinators setting the exams rather than individual teachers. All in-class tests, quizzes and exams are designed, shared, and administered for different groups of students by all teachers in the language centres. Such a process might minimise the individual teachers' chances for adjusting assessment strategies unless such a move is approved by the department.

Teachers were asked about their perceptions pertaining to factors affecting student feedback (Figure3). The analysis of item (4) revealed that $43 \%$ agreed that grade seekers' feedback on their teachers is influenced by the results they get, while $47 \%$ of the respondents were uncertain of their views. Only $10 \%$ disagreed with the statement. Interestingly, the analysis of item (6) revealed that $70 \%$ agreed, and $20 \%$ were uncertain that peer views on a teacher may influence other students' decisions in providing feedback, while only $10 \%$ disagreed with the idea. This result draws attention to the necessity of educating students on the value of their comments 


\section{International Journal of Applied Linguistics \& English Literature \\ ISSN 2200-3592 (Print), ISSN 2200-3452 (Online) \\ Vol. 1 No. 7; November 2012 [Special Issue on Applied Linguistics]}

and their roles as key players in the quality teaching-learning process. Item (8) on the other hand, focused on the relation between learners' own experience in a particular course and their evaluation of the teacher who teaches it.

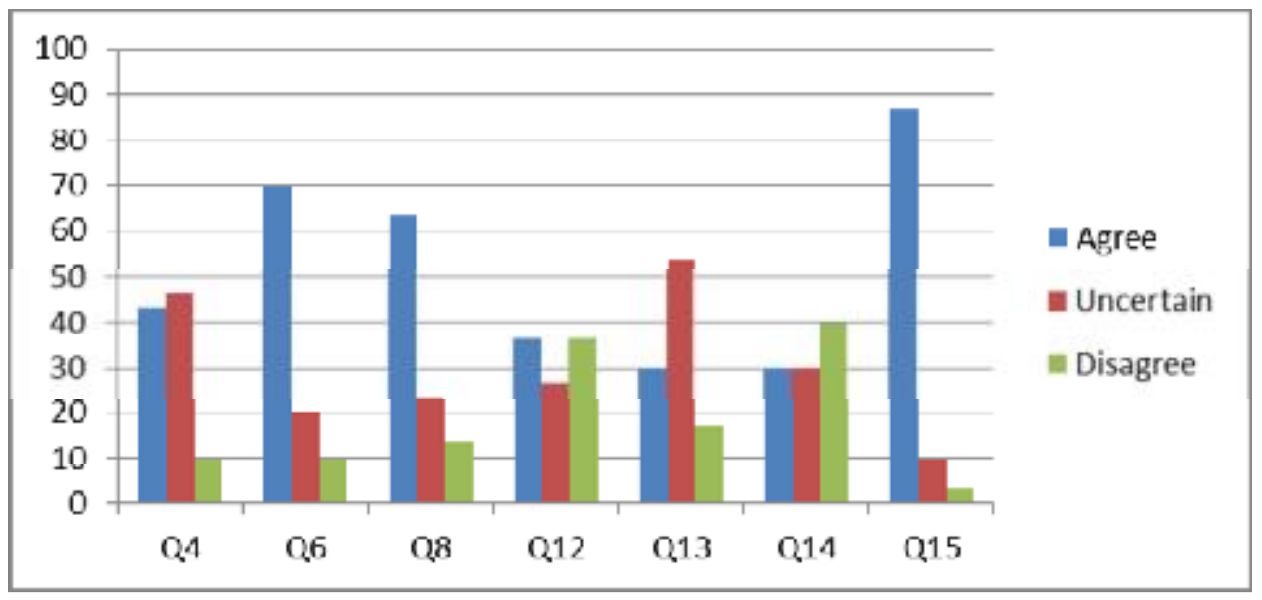

Figure3-T: Factors affecting student feedback

The analysis demonstrated that $63 \%$ of the participants agreed, and $13 \%$ disagreed that the students' learning experience influences their decision in providing feedback on the teacher and the course they learn. On the other hand, 23\% remained uncertain. The analysis of item (12) revealed that the respondents scored the same percentage $37 \%$ for supporting and opposing the idea that too many class activities form negative tendency in the students. However, $26 \%$ of the respondents were uncertain of their stand. This result is significant because some teachers hold the view that too-tasking teaching might discourage deep learning and positive perceptions towards English. Thus, teachers might need to reflect on how to maintain a balanced teaching practice for quality learning. The analysis of item (13) revealed that 30\% agreed, and $17 \%$ disagreed that less performing students tend to rate their teachers low, while 53\% remained uncertain. Item (14) examined the teacher's personality as a factor that might influence students' views when giving their feedback on teaching and learning. The analysis of this item revealed that the respondents scored the same percentage $30 \%$ for supporting the statement and expressing uncertainty as well, while $40 \%$ disagreed with it. The analysis also revealed another interesting finding with regard to the way the teacher treats his/her class and the effect of that on the student feedback. The majority of the respondents, $87 \%$ agreed that the teacher's behaviour towards class determines the type of feedback the students provide. On the other hand, 10\% were uncertain, and 3\% disagreed with the statement. These findings are significant as they serve the study's fifth question which focuses on the quality of feedback provided by students. It is a pertinent fact that understanding the factors affecting students' views enables institutions to measure the extent to which student feedback confines to quality standards. Furthermore, it could be argued that teachers need to be continually sensitive to their students' needs, aware of the conditions of the learning setting, and develop the ability to control the teaching and learning process by taking the appropriate decision at the appropriate time.

Figure4 above summarises the respondents' perceptions about feedback quality. The analysis of item (7) revealed that the respondents scored $37 \%, 33 \%$, and $30 \%$ for agreed, uncertain, and disagreed respectively in relation to their perception about the students' ability to judge the knowledge of the teacher. In the same context, the analysis of item (9) revealed that 33\% agreed that learners are unable to judge the teachers' ability to teach, while $47 \%$ believed the students are able to do so. On the other hand, $20 \%$ were uncertain about their stand. The relatively higher percentage of the respondents who valued student feedback suggests that there is growing awareness among teachers for the significance of obtaining students' views for the purposes of quality teaching and teacher growth and professional development.

The analysis of item (10) revealed that $47 \%$ believed that student feedback may not be reflective of the classroom reality, while other respondents scored the same value $27 \%$ for both disagreement with and uncertainty about the idea in the statement. 


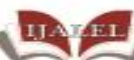

International Journal of Applied Linguistics \& English Literature

ISSN 2200-3592 (Print), ISSN 2200-3452 (Online)

Vol. 1 No. 7; November 2012 [Special Issue on Applied Linguistics]

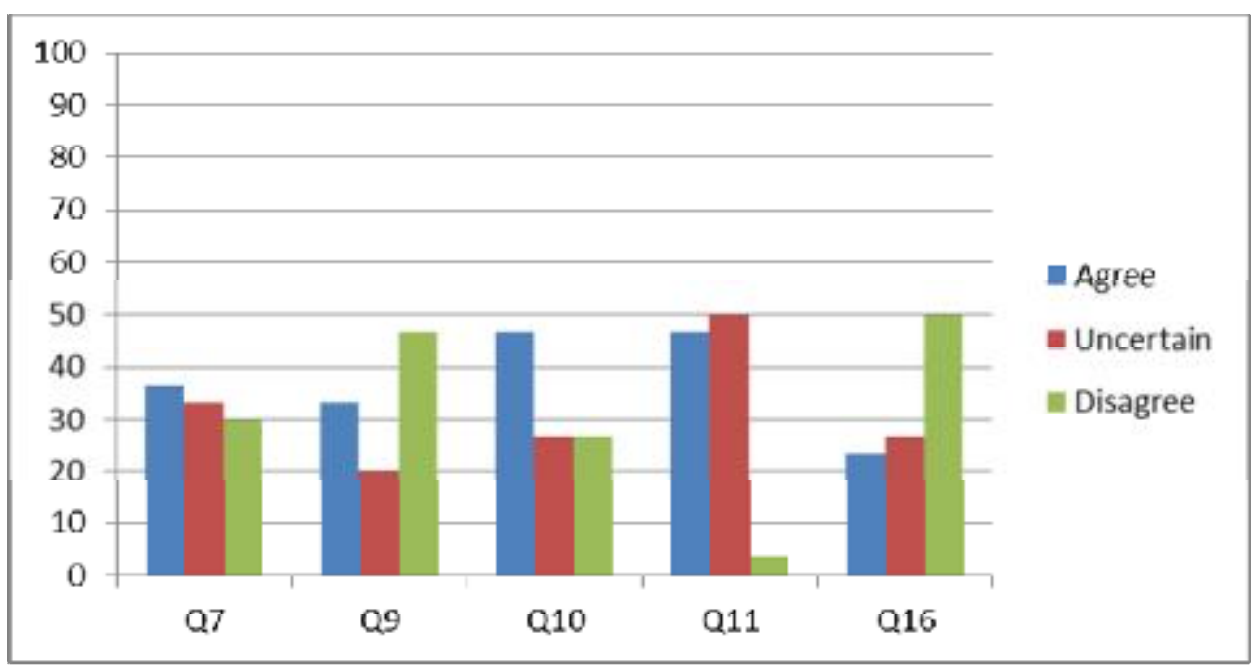

Figure4-T: Feedback quality

This mixed view however, contradicts with the respondents' score in item (9) where $47 \%$ of the teachers felt that even with little or no knowledge of the language; learners are still able to judge the teachers' ability to teach. The analysis of item (11) revealed that $47 \%$ agreed that when students participate in providing feedback on their learning experience, they are able to become reflective as well. However, $50 \%$ were uncertain, while $3 \%$ disagreed with the statement. The result also revealed that $23 \%$ agreed with item (16) which suggested that teachers should please students to avoid negative feedback. The majority of the respondents with $50 \%$ disagreed while $27 \%$ were uncertain. This result is consistent with the analysis of items $(1,5, \& 17$-Figure 1$)$ in addressing the issue raised in the study's first question. In addition, the result indicates that teachers uphold professionalism in teaching and commit to quality standards.

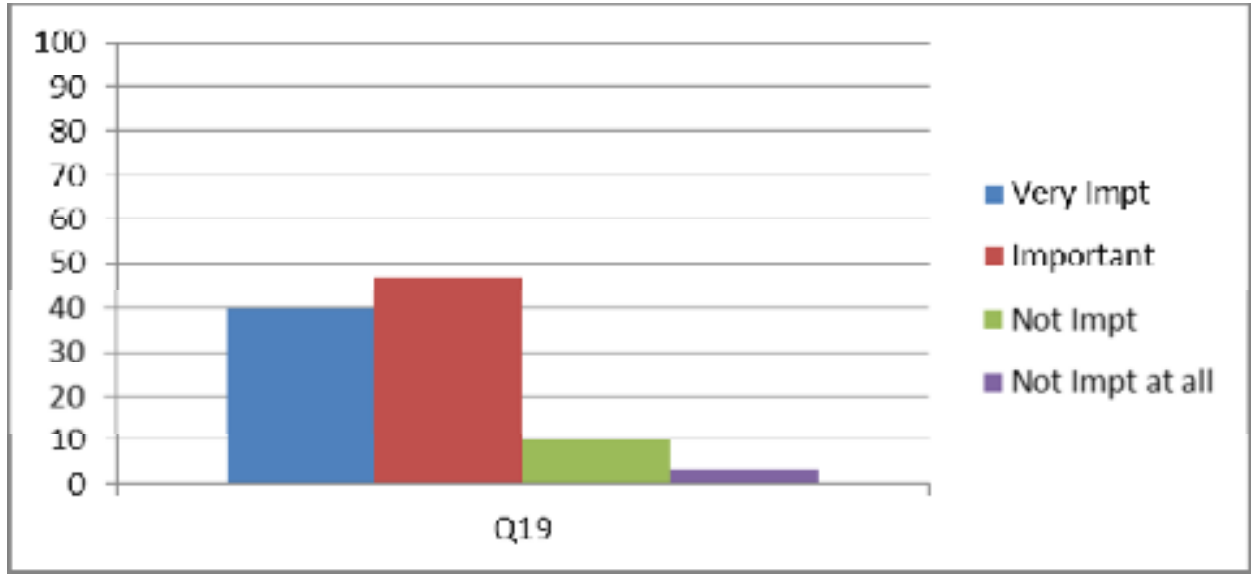

Figure5-T: Training students for quality feedback

Item (19) in Figure5 above focuses on training students in the quality procedures before involving them in any activity of evaluating teaching and learning. The analysis revealed that $87 \%$ of the respondents perceived training students an important requirement for quality feedback. No doubt educating students on the quality culture creates opportunities for students' transformative reflection and more positive focus on their learning experience. 


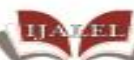

International Journal of Applied Linguistics \& English Literature ISSN 2200-3592 (Print), ISSN 2200-3452 (Online)

Vol. 1 No. 7; November 2012 [Special Issue on Applied Linguistics]

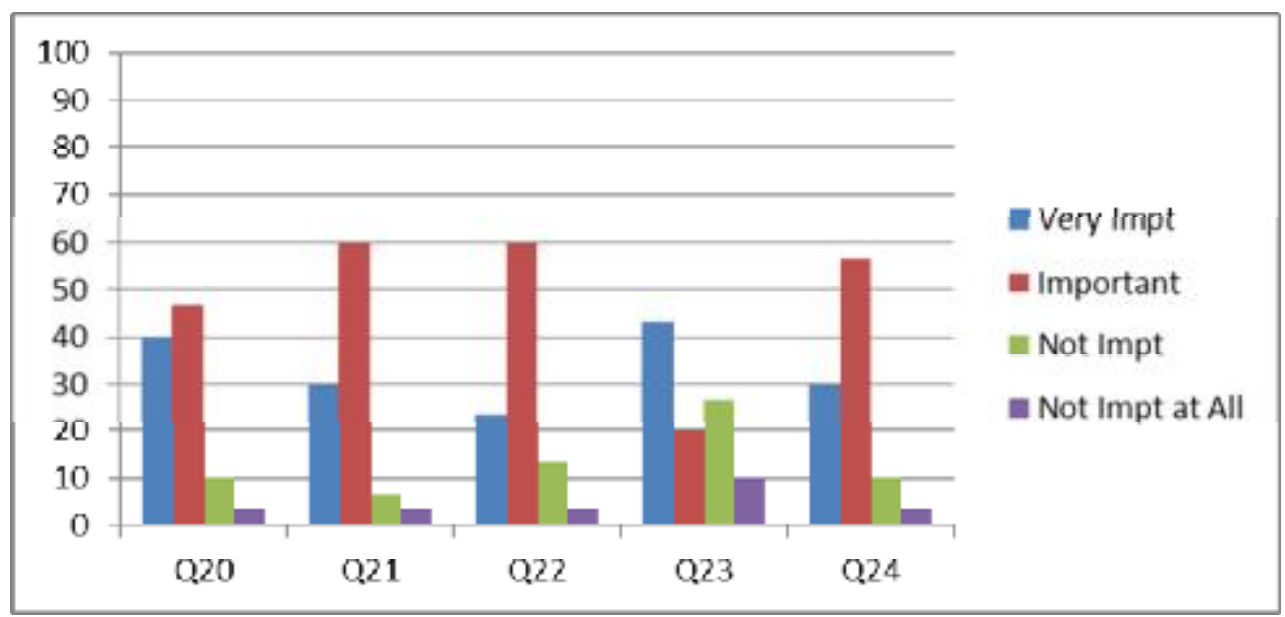

Figure6-T: Significance of learner feedback

Figure6 above presents interesting results pertaining to teachers' perceptions about the significance of the student feedback. The analysis of item (20) revealed that $40 \%$ of the respondents perceived learners' feedback on the teachers' communication skills and pronunciation clarity as very important, and $47 \%$ believed it is important to obtain the views of students on teachers' communication skills and pronunciation. On the other hand, $10 \%$ perceived it not important, while 3\% considered it not important at all. In the same vein, item (21) revealed that $30 \%$ and $60 \%$ of the respondents perceived student feedback on teachers' skills very important and important respectively. The rest of the respondents perceived it not important with $7 \%$, and not important at all with $3 \%$. Moreover, item (22) revealed the same result with $23 \%$ of the respondents viewing it very important to explore students' views on the teachers' availability and accessibility during and after class, and $60 \%$ supported the idea as important. On the other hand, 13\% viewed it not important and 3\% not important at all. Student feedback on the way tests and quizzes are conducted (item 23 ) was perceived by $43 \%$ of the respondents very important, and by $20 \%$ important, while $27 \%$ perceived it not important. Only $10 \%$ viewed it not important at all. Item (24) examined teachers' views on exploring students' feelings about the feedback they receive from their teachers. The analysis revealed that $30 \%$ of the respondents believed that it is very important to explore the students' perceptions about their teachers' feedback, and 57\% considered it important. $10 \%$ of the respondents viewed it not important and 3\% perceived it not important at all. The overall result here serves the study's first question and reveals that the respondents valued student feedback as significant for quality teaching. It is also observed that the respondents showed consistency in their responses to items $21 \& 22$. The higher percentages in every item were scored to show the respondents' support for student feedback. However, it is of paramount importance to explore students' perceptions about the feedback they provide on their learning experience and teachers as well. By so doing, institutions of higher learning will be able to set their agenda for maximizing quality assurance mechanisms in their various practices and operations. The following section discusses the analysis of the student questionnaire.

Figure7 presents the students' awareness of the value of their own feedback on both learning experience and their teachers as well. The analysis of item (1) in the questionnaire distributed to students revealed that $45 \%$ of the students agreed that they were aware of the significance of their feedback on learning and teaching. However, $44 \%$ were uncertain of their stand, while $11 \%$ disagreed with statement. It is worth noting that teachers have given student feedback great value and importance (Figure1, items $1 \& 5$ ). This result suggests that some students need to be educated on the QA system and procedures. This finding also serves the study's second question about whether teachers and students hold compatible understanding of feedback as a quality requirement. The analysis of item (2) revealed that $55 \%$ of the respondents agreed, and $10 \%$ disagreed with the idea of making it mandatory for foundation students to participate in providing feedback on their experience of learning and teaching. On the other hand, $35 \%$ of the students remained uncertain. The study also attempted to examine the degree of the students' seriousness while filling the feedback survey forms. 


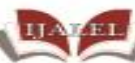

International Journal of Applied Linguistics \& English Literature

ISSN 2200-3592 (Print), ISSN 2200-3452 (Online)

Vol. 1 No. 7; November 2012 [Special Issue on Applied Linguistics]

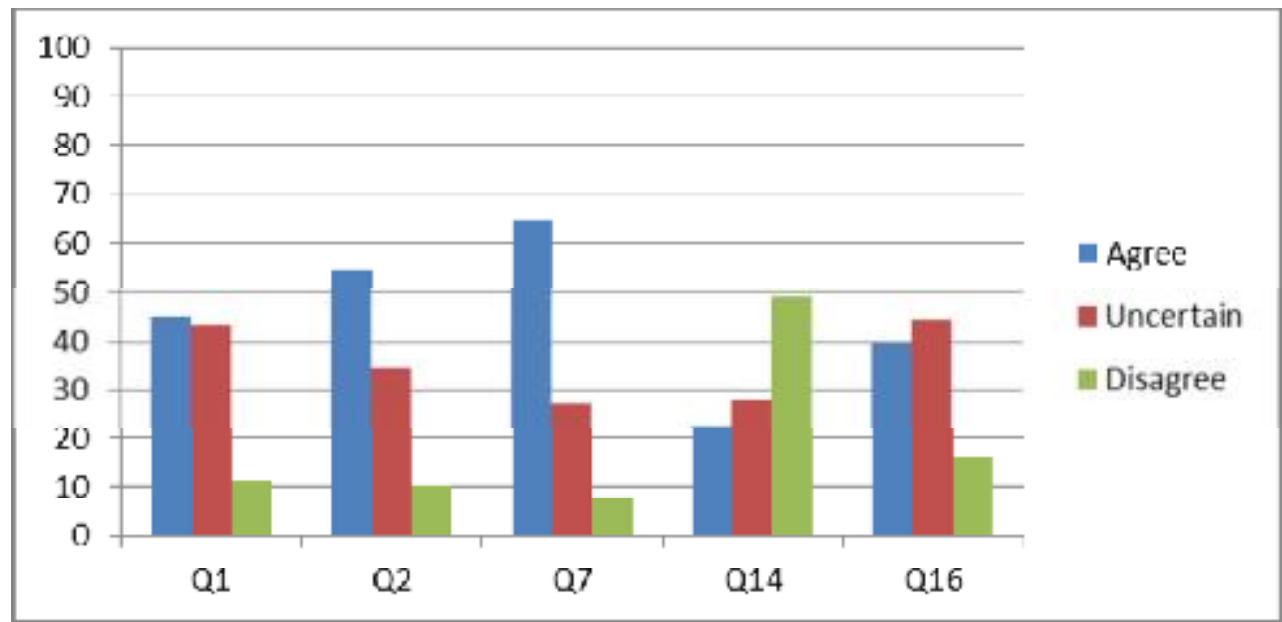

Student Questionnaire (Figures 7- 11)

Figure7-S: Awareness of feedback significance

The analysis of item (7) revealed that $65 \%$ agreed and only $8 \%$ disagreed that they read the feedback form carefully before responding to it, while $27 \%$ were uncertain. It could be argued that training students on the significance of their feedback may enhance their motivation for more active and serious participation in the evaluation process. For the QA tools to operate effectively, all key participants must play their roles with clear understanding of the objectives of such tools. Item (14) presented mixed responses pertaining to the accuracy of the student feedback on different teachers where $23 \%$ agreed and $49 \%$ disagreed with the idea that they tend to provide the same feedback on all teachers. Some of the respondents remained uncertain about their stand scoring $28 \%$ of the total population. Students need to view teachers as individuals with distinct personalities and teaching skills. Item (16) focused on the relation between the marks the students obtain in a particular course and their feedback on the teacher who teaches that course. $40 \%$ of the students agreed and $16 \%$ disagreed that they provide positive comments on their teachers even if they get poor marks. However, 44\% remained uncertain about their stand. This result suggests that some students are sceptical about their ability to maintain objectivity when giving feedback if the assessments affect their grades. It is imperative to inculcate in students the values of providing constructive feedback by being more reflective learners.

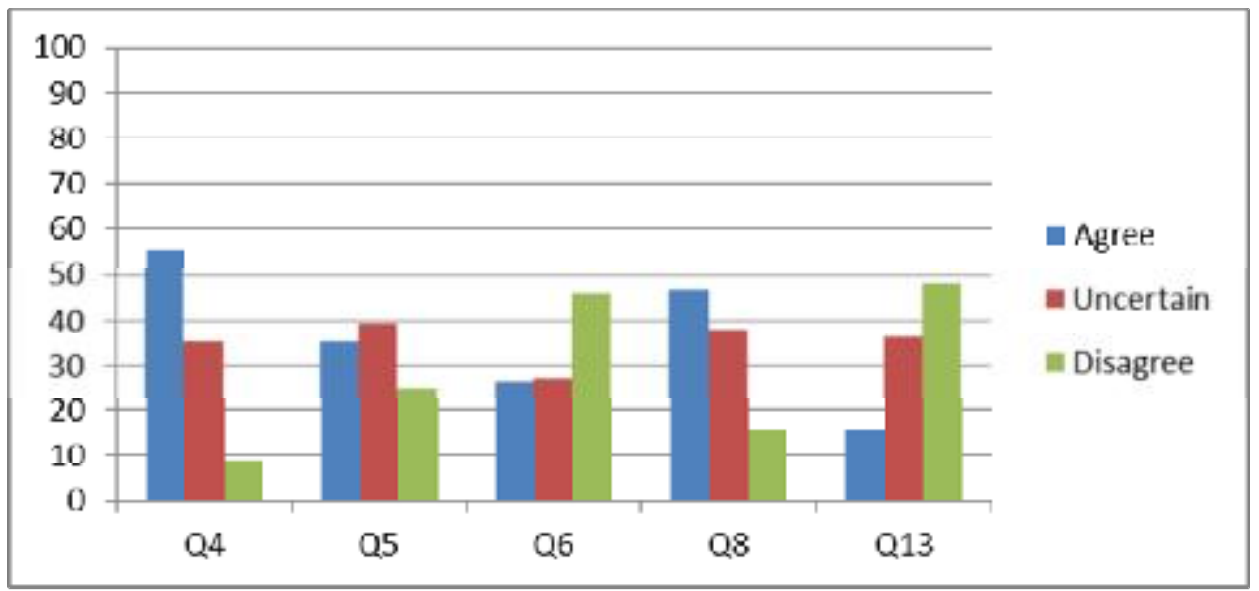

Figure8-S: Factors shaping students' decisions

The study also attempted to explore factors might affect students' decisions when evaluating teachers (Figure8). The analysis of item (4) revealed that 56\% agreed and 9\% disagreed that they always expect to get higher marks,
Page $\mid 97$ 


\section{International Journal of Applied Linguistics \& English Literature}

ISSN 2200-3592 (Print), ISSN 2200-3452 (Online)

Vol. 1 No. 7; November 2012 [Special Issue on Applied Linguistics]

while $35 \%$ reported uncertainty about their stand. This result accords with the teachers' fear for the effect of grade-seekers' revenge (Figure3, item4). The analysis of item (5), on the other hand, revealed that $35 \%$ agreed and $25 \%$ disagreed that they share information with colleagues about teachers before taking any subject with them. $40 \%$ of the respondents remained uncertain. This result contradicts with the teachers' perceptions about the impact of peer factor on student feedback (Figure3, item6). This result also answers the study's second question about the uniformity in understanding quality feedback by teachers and students alike. Item (6) attempted to assess the influence of peers on students when evaluating their teachers. The analysis revealed that the respondents scored the same percentage of $27 \%$ for both 'agree' and 'uncertain' while $46 \%$ disagreed that they sometimes follow friends when evaluating teachers. This result suggests that majority of the students maintain independence while filling the teacher efficiency surveys. The analysis of item (8) revealed that $47 \%$ agreed and $15 \%$ disagreed with the idea that they disfavour multi-tasking teachers. $38 \%$ of the respondents remained uncertain. Item (13) in the students' questionnaire explored the students' reaction towards teacher feedback. The analysis of this item suggested that $15 \%$ of the respondents agreed and $48 \%$ disagreed that they retaliate by rating the teacher low if the teachers give them low marks. However, $36 \%$ of the students remained uncertain.

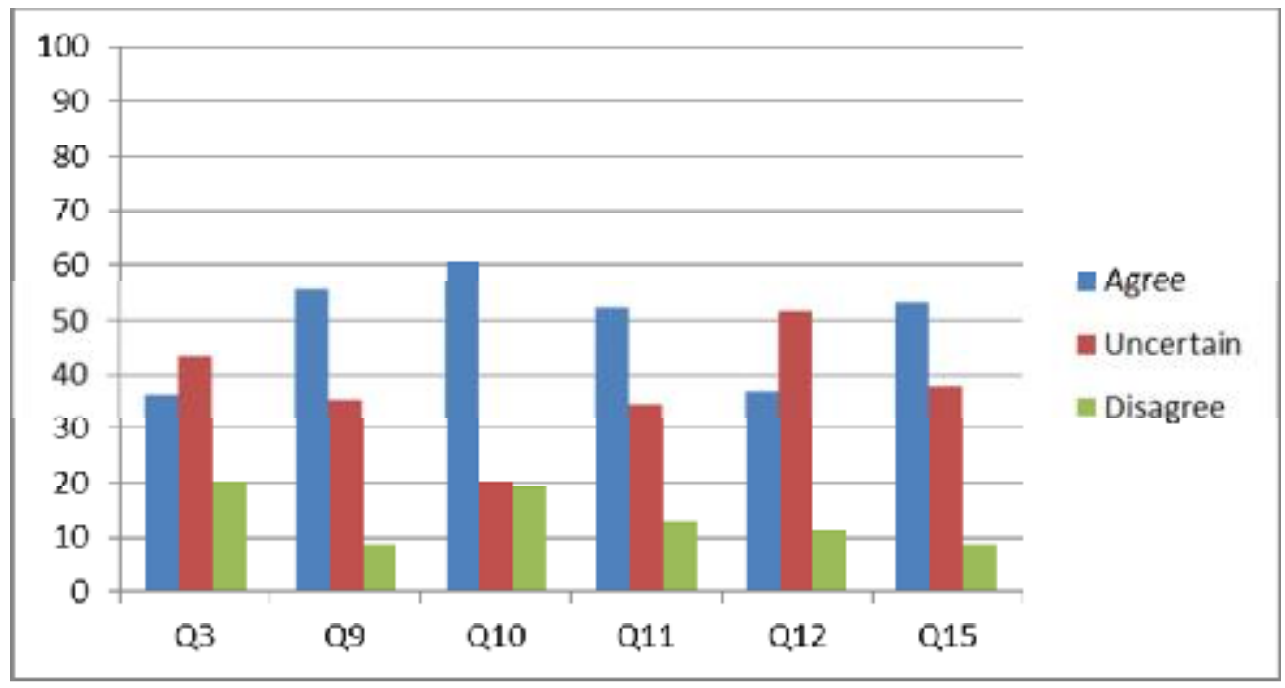

Figure9-S: Teaching skills \& teacher personality

Figure9 above summarises the students' perceptions on their teachers' skills and personal traits and their preferences when giving feedback. The analysis of item (3) revealed that $36 \%$ of the students agreed and $20 \%$ disagreed that evaluating teachers is unnecessary because teachers are knowledgeable enough, while $44 \%$ remained uncertain. The analysis of item (9) also revealed that $56 \%$ of the students agreed that they found teacher feedback useful, while 35\% were uncertain about their opinion. Only $9 \%$ disagreed with the statement. Item (10) explored the students' perceptions on their teacher encouragement and motivation. The analysis suggested that $60 \%$ of the respondents agreed, and $19 \%$ disagreed that their teachers motivate them, while $20 \%$ expressed uncertainty about their stand. Teachers' adherence to the time allotted for classes was also explored (item 11). The analysis revealed that $52 \%$ of the students agreed, and $13 \%$ disagreed that they like the teacher who finishes classes early. However, $35 \%$ of the respondents remained uncertain. The analysis of item (12) which attempted to explore the students' views on multi-tasking classes revealed that $37 \%$ of the respondents agreed, and $11 \%$ disagreed that they do not support classes of multi-tasking and practices nature. $52 \%$ of the students remained uncertain of their views. The analysis of item (15) suggested that $53 \%$ of the respondents agreed that they are concerned with the way teachers treat them in class. On the other hand, $38 \%$ of the students were uncertain, while $9 \%$ disagreed with the statement. This finding supports the study's third question which addresses the way students evaluate teachers. This result also suggests that in all ESL/EFL classes teachers may expect to have some meticulous students. Professional teachers need to be able to deal with all the different class circumstances and be able to make the appropriate decisions whenever it is required. 


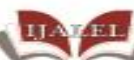

International Journal of Applied Linguistics \& English Literature

ISSN 2200-3592 (Print), ISSN 2200-3452 (Online)

Vol. 1 No. 7; November 2012 [Special Issue on Applied Linguistics]

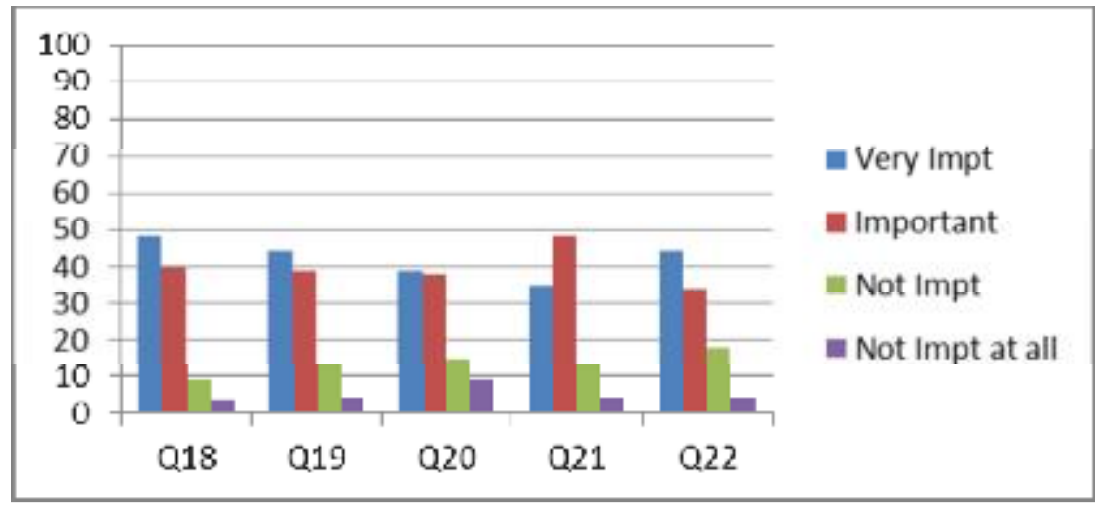

Figure10-S: Focus on the teacher

Figure10 above summarises the students' views on teachers' communication skills in terms of comprehensibility and pronunciation. The analysis revealed that $48 \%$ of the respondents believed that it is very important for the institutions to know the students' views on the teachers' communication skills, and $40 \%$ viewed it important, while $9 \%$ believed it is not important to do so. Only 3\% of the respondents perceived it not important at all. On the other hand, the analysis of item (19) revealed that $44 \%$ of the respondents believed it is very important, and $39 \%$ believed it is important to explore students' views on the teaching skills and methods of teachers. On the other hand, $13 \%$ of the respondents believed it is not important and $4 \%$ viewed it not important at all to seek student feedback on teachers' teaching skills. The analysis of item (20) revealed that $39 \%$ of the respondents and $38 \%$ of them believed that it is very important and important respectively, to receive student feedback on the accessibility and availability of teachers during class and consultation sessions as well. 15\% of the respondents believed it is not important and 9\% believed it is important at all to do so. The analysis of item (21) revealed that $39 \%$ of the respondents believed that it is very important to get student feedback on the assessment procedures. In addition, $38 \%$ of the respondents believed that their feedback on the way tests and quizzes are conducted is important, while $13 \%$ perceived that as not important, and $4 \%$ as not important at all. The analysis of item (22) revealed that $44 \%$ of the respondents believed that their feedback on teachers' comments is very important and $34 \%$ of them also believed it is important to do so. On the other hand, $18 \%$ believed it is not important while $4 \%$ perceived that as not important at all. The overall result of the analysis of the items in Figure10 is consistent with the analysis of the items in Figure9 as it serves the study's third question. The result also suggests that students hold high value and support for their involvement in the teaching evaluation process. This result is consistent with the teachers' responses (Figure6) in holding positive views about students' participation in teaching evaluation.

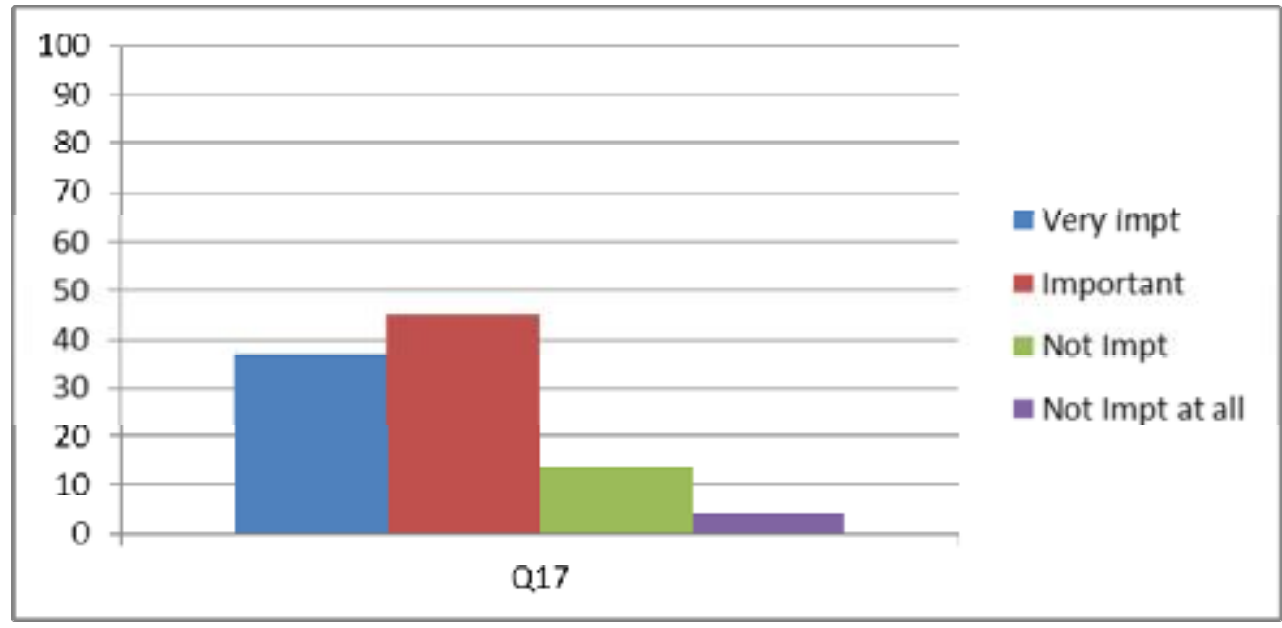

Figure11-S: Training for quality feedback 


\section{International Journal of Applied Linguistics \& English Literature \\ ISSN 2200-3592 (Print), ISSN 2200-3452 (Online)}

Vol. 1 No. 7; November 2012 [Special Issue on Applied Linguistics]

The analysis of Figure11 revealed that $37 \%$ of the respondents perceived training students for providing quality feedback as a very important move, and $45 \%$ of them viewed it as important. On the other hand, $14 \%$ of the respondents suggested it is not important, while $4 \%$ believed it is not important at all. This result shows consistency with the analysis of teachers' positive perceptions (Figure5) about training students on QA matters especially evaluation of teaching and learning before involving them in such activities.

\section{Concluding Remarks}

This study is set to explore the views of English language teachers and the General Foundation Programme (GFP) students on student feedback and its impact on the quality of teaching and learning. The analysis of the teacher and student questionnaires revealed varieties of perceptions by teachers and students about student feedback on teaching and learning. Teachers were found to value student feedback, while some students lacked awareness of its significance. In addition, teachers were divided about the 'after-feedback' stage as to whether or not discuss students' comments in class. This might justify partially the teachers' fear for students' 'revenge' especially by those who attain low marks in the subjects they learn. Thus, educating students on reflective learning is deemed imperative in transforming them to active learners rather than grade seekers. Moreover, embracing creative and constructive teaching methods grounded on strong support for the social dimension will provide opportunities for quality teaching and learning. Students' participation in evaluating their experience of teaching and learning is necessary for quality teaching and learning and has to be geared into transforming students from viewing learning as passing exam activity to more reflection on learning.

\section{References}

Biggs, J. \& Tang, C. (2007). Teaching for quality learning at university (3rd ed.). New York:

Society for Research into Higher Education \& Open University Press.

Cheng, M. (2011). 'Transforming the learner' versus 'passing the exam': Understanding the gap between academic and student definitions of quality. Quality in Higher Education, 17, (1), 3-17. Cook, G. (2003). Introduction to applied linguistics. Oxford: Oxford University Press.

Cowan, J. (2006). On becoming an innovative university teacher: Reflection in action (2nd ed.).

New York: Society for Research into Higher Education \& Open University Press.

Danielson, C., \& McGreal, T. (2000). Teacher evaluation. USA: Educational Testing Service.

Douglas, J. \& Douglas, A. (2006). Evaluating teaching quality. Quality in Higher Education, 12, (1), 3-13.

Jean, G., \& Simard, D. (2011). Grammar teaching and learning in L2: Necessary, but boring.

Foreign Language Annals, 44, (3), 467-494.

Josefan, K., Pobeiga, J., \& Strahlman, C. (2011). Student participation in developing student feedback. Quality in Higher Education, 17, (2), 257-262.

Leckey, J., \& Neill, N. (2001). Quantifying quality: The importance of student feedback. Quality in Higher Education, 7, (1), 19-32.

Zerihun, Z., Beishuizen, J., \& Van Os, W. (2011). Conceptions and practices in teaching and learning: implications for the evaluation of teaching quality. Quality in Higher Education, 17, (2), 151-161. 


\section{International Journal of Applied Linguistics \& English Literature \\ ISSN 2200-3592 (Print), ISSN 2200-3452 (Online)}

Vol. 1 No. 7; November 2012 [Special Issue on Applied Linguistics]

\section{Appendix (A)}

Teacher Questionnaire

\section{Dear colleagues:}

This questionnaire forms part of a study exploring English teachers' and foundation students' perceptions about the involvement of students in evaluating teachers. I would therefore very much appreciate if you could spend a little time to respond honestly and objectively to this questionnaire. Your responses will help me to identify preferences, and perceptions of teachers and students within quality teaching and learning context. Kindly be informed that the questionnaire is conducted for research purposes only.

Please respond to All the items in this questionnaire precisely.

I thank you in advance for your cooperation and help with this research.

Please respond to the following statements by placing a tick $(\sqrt{ })$ mark in the box that represents your attitude.

$$
\text { Agree }=3
$$

Uncertain $=2$

Disagree $=1$

\begin{tabular}{|c|c|c|c|c|}
\hline & Items & 3 & 2 & 1 \\
\hline 1 & Student feedback is not necessary. & & & \\
\hline 2 & Student feedback enables me to reflect on my teaching. & & & \\
\hline 3 & $\begin{array}{l}\text { I always adjust my teaching skills after receiving the students' } \\
\text { comments. }\end{array}$ & & & \\
\hline 4 & Grade seekers rate teachers according to the results they get. & & & \\
\hline 5 & Student feedback should be discussed in class. & & & \\
\hline 6 & Students sometimes follow their peers in evaluating teachers. & & & \\
\hline 7 & Students are able to judge the knowledge base of the teacher. & & & \\
\hline 8 & $\begin{array}{l}\text { Students' experience in learning a course influences their feedback on } \\
\text { that course teacher. }\end{array}$ & & & \\
\hline 9 & $\begin{array}{l}\text { Since the student is still a learner with little or no knowledge of the } \\
\text { language, s/he is no position to judge the teacher's ability to teach. }\end{array}$ & & & \\
\hline 10 & Student feedback may not reflect the actual classroom reality. & & & \\
\hline 11 & $\begin{array}{l}\text { The involvement of students in evaluating the courses they learn and } \\
\text { the teachers enables the students to become reflective learners. }\end{array}$ & & & \\
\hline 12 & $\begin{array}{l}\text { Students normally don't prefer too many language activities and } \\
\text { practices. }\end{array}$ & & & \\
\hline 13 & The weak students usually rate their teachers low. & & & \\
\hline 14 & $\begin{array}{l}\text { Students are concerned about their teacher's personality more than the } \\
\text { language course content. }\end{array}$ & & & \\
\hline 15 & The way the teacher treats class influences the students' feedback. & & & \\
\hline 16 & $\begin{array}{l}\text { Since the student is a learner and an 'authority', teachers have to } \\
\text { please them. }\end{array}$ & & & \\
\hline 17 & Student feedback should focus on the course they learn only. & & & \\
\hline 18 & Students' comments affect my assessment strategies. & & & \\
\hline
\end{tabular}


International Journal of Applied Linguistics \& English Literature

ISSN 2200-3592 (Print), ISSN 2200-3452 (Online)

Vol. 1 No. 7; November 2012 [Special Issue on Applied Linguistics]

\begin{tabular}{|c|c|c|c|c|c|}
\hline & \multirow{2}{*}{$\begin{array}{l}\text { Very important }=4 \\
\text { statement }\end{array}$} & \multicolumn{4}{|c|}{ Not important at all $=1$} \\
\hline & & 4 & 3 & 2 & 1 \\
\hline 19 & $\begin{array}{l}\text { Training students on feedback process as quality assurance } \\
\text { requirement. }\end{array}$ & & & & \\
\hline 20 & $\begin{array}{l}\text { Getting the learners' views on teachers' communication skills in terms } \\
\text { of pronunciation and comprehensibility. }\end{array}$ & & & & \\
\hline 21 & Students' views about the teaching skills of teachers. & & & & \\
\hline 22 & $\begin{array}{l}\text { Knowing students' views about the teachers' availability and } \\
\text { accessibility in and out of the classroom. }\end{array}$ & & & & \\
\hline 23 & Exploring students' views on the way tests and quizzes are conducted. & & & & \\
\hline 24 & $\begin{array}{l}\text { Exploring students' perceptions about the feedback given by their } \\
\text { teachers. }\end{array}$ & & & & \\
\hline 25 & If you have other comments to offer you may do so below & & & & \\
\hline
\end{tabular}

\section{Appendix (B)}

Student Questionnaire

\section{Dear students:}

This questionnaire forms part of a study exploring English teachers' and foundation students' perceptions about the involvement of students in evaluating teachers. I would therefore very much appreciate if you could spend a little time to respond honestly and objectively to this questionnaire. Your responses will help me to identify preferences, and perceptions of teachers and students within quality teaching and learning context. Kindly be informed that the questionnaire is conducted for research purposes only.

Please respond to All the items in this questionnaire precisely.

I thank you in advance for your cooperation and help with this research.

Please respond to the following statements by placing a tick $(\sqrt{ })$ mark in the box that represents your attitude.

Agree $=3$

Uncertain $=2$

Disagree $=1$

\begin{tabular}{|c|c|c|c|c|}
\hline & Items & 3 & 2 & 1 \\
\hline 1 & My feedback is the most important information for teachers. & & & \\
\hline 2 & $\begin{array}{l}\text { All foundation students must give feedback about the courses they } \\
\text { learn and the teachers as well. }\end{array}$ & & & \\
\hline 3 & Since my teachers know everything it is not useful to evaluate them. & & & \\
\hline 4 & I always expect to get higher marks in my subjects. & & & \\
\hline 5 & $\begin{array}{l}\text { I collect information about my teachers before taking any course with } \\
\text { them. }\end{array}$ & & & \\
\hline 6 & I sometimes follow my friends in evaluating teachers. & & & \\
\hline 7 & I read the feedback form carefully before answering it. & & & \\
\hline 8 & Students don't like the teacher who gives a lot of work. & & & \\
\hline
\end{tabular}


International Journal of Applied Linguistics \& English Literature

ISSN 2200-3592 (Print), ISSN 2200-3452 (Online)

Vol. 1 No. 7; November 2012 [Special Issue on Applied Linguistics]

\begin{tabular}{|c|c|c|c|}
\hline 9 & Teachers' comments on my work are always useful. & & \\
\hline 10 & My teachers always encourage me to learn English. & & \\
\hline 11 & Teachers who finish their classes early are good. & & \\
\hline 12 & $\begin{array}{l}\text { Students normally don't like too many language activities and } \\
\text { practices. }\end{array}$ & & \\
\hline 13 & $\begin{array}{l}\text { If I get less mark in my exams, I also give the teacher less mark in the } \\
\text { feedback form. }\end{array}$ & & \\
\hline 14 & I give the same feedback on all my teachers. & & \\
\hline 15 & I care more about the way the teacher treats us in class. & & \\
\hline 16 & I give good feedback on my teacher even if I get low marks. & & \\
\hline & Very important $=4$ & & tant at all=1 \\
\hline & statement & 3 & 2 \\
\hline 17 & $\begin{array}{l}\text { Training students on feedback process before asking them to evaluate } \\
\text { their teachers. }\end{array}$ & & \\
\hline 18 & $\begin{array}{l}\text { Getting the students' views on teachers' communication skills in terms } \\
\text { of pronunciation and comprehensibility. }\end{array}$ & & \\
\hline 19 & Students' views about the teaching skills of teachers. & & \\
\hline 20 & $\begin{array}{l}\text { Knowing students' views about the teachers' availability and } \\
\text { accessibility in and out of the classroom. }\end{array}$ & & \\
\hline 21 & Exploring students' views on the way tests and quizzes are conducted. & & \\
\hline 22 & $\begin{array}{l}\text { Exploring students' perceptions about the feedback given by their } \\
\text { teachers. }\end{array}$ & & \\
\hline 23 & If you have other comments to offer you may do so below. & & \\
\hline
\end{tabular}

